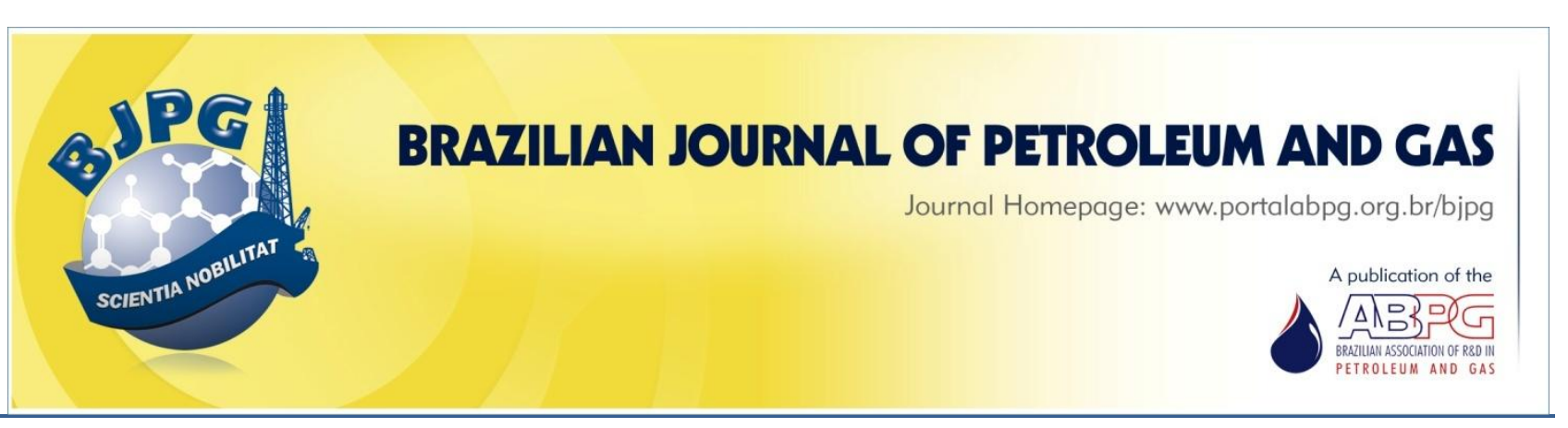

\title{
DYNAMIC ADSORPTION OF $\mathrm{H}_{2} \mathrm{~S}$ IN A FIXED BED OF SEWAGE SLUDGE PYROLYSIS CHAR
}

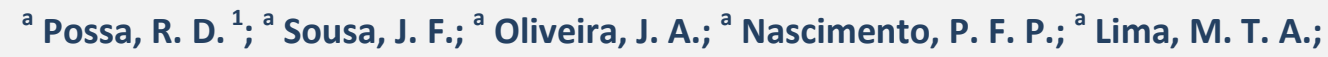 \\ ${ }^{\text {a } B r a n d a ̃ o, ~ I . ~ B . ; ~}{ }^{\text {B } B e z e r r a, ~ M . ~ B . ~ D . ~}$ \\ ${ }^{\mathrm{a}}$ Federal University of Rio Grande do Norte (UFRN), Graduate Program in Chemical Engineering, Natal - RN - Brazil \\ Received: 07.08.2017 / Revised: 10.05.2018 / Accepted: 10.05.2018 / Published on line: 11.07.2018
}

\begin{abstract}
In this work, sewage sludge char was tested as a $\mathrm{H}_{2} \mathrm{~S}$ adsorbent in a fixed-bed column, at $25{ }^{\circ} \mathrm{C}$. The char was activated physically and chemically (with $\mathrm{HCl}$ or $\mathrm{KOH}$ ) to enhance textural properties. Commercial activated carbon impregnated with iron was also tested for comparison. The column was filled with 18.24 $\mathrm{g}$ of char and, then, fed $\mathrm{H}_{2} \mathrm{~S}(600 \mathrm{ppm})$ under $50 \mathrm{~mL} / \mathrm{min}$. The effluent gas composition was measured via photocolorimetry and the data was used to plot breakthrough curves. A mathematical modeling was used to estimate parameters such as axial diffusivity, effective intraparticle diffusivity, and external mass transfer coefficient. The main results show that the adsorption capacities varied from 7.2 to 657.60 $\mathrm{mgH}_{2} \mathrm{~S} / \mathrm{g}_{\text {ads }}$. The percentages of $\mathrm{H}_{2} \mathrm{~S}$ adsorbed varied from 43.36 to $59.04 \%$. $\mathrm{HCl}$ proved to be more efficient than $\mathrm{KOH}$. Due to improved textural properties, the commercial activated carbon outperformed $\left(69.15 \%, 12,527.80 \mathrm{mgH}_{2} \mathrm{~S} / \mathrm{g}_{\text {ads }}\right)$ all char samples.
\end{abstract}

\section{KEYWORDS}

$\mathrm{H}_{2} \mathrm{~S}$ adsorption; sewage sludge pyrolysis char; breakthrough curve; mass transfer zone; fixed-bed column

\footnotetext{
${ }^{1}$ To whom all correspondence should be addressed.

Address: Universidade Federal do Rio Grande do Norte, PPGEQ - Programa de Pós-Graduação em Engenharia Química, Campus Universitário , Lagoa Nova, Natal/RN, Brasil.

ZIP Code: 59078-970 | e-mail: rosangeladpossa@gmail.com

doi:10.5419/bjpg2018-0008
} 


\section{INTRODUCTION}

The biogas obtained from the anaerobic digestion of swine manure is an attractive energy source due to its high methane content, ranging from 60 to $80 \%$ (Ciotola \& Marting, 2011). However, the presence of hydrogen sulfide makes the biogas highly corrosive, reducing the life expectancy of electromechanical devices used for energy generation and conversion (Molino et al., 2013).

Adsorption is one of the most common ways of capturing hydrogen sulfide due to the low cost and energy consumption involved in the process. Some of the commonly used adsorbents are: activated carbon, zeolites, and membranes of organic and inorganic materials, such as polymers, ceramics, silicon carbide, and stainless steel (Ros et al., 2006). Although these materials are efficient, there are others that are of interest, such as pyrolysis chars, which are rich in carbon and metals (Sousa et al., 2016, Seredych \& Bandosz 2007).

Out of these materials, sewage sludge char is the most used one because of its specific area that is usually higher in comparison to the chars from lignocellulose-based biomass. Due to the limited textural properties, pyrolysis chars are not expected to have the same performance as activated carbon. Some of the advantages of using chars are: they do not need to be impregnated with metals and are cost-free. They also can be easily cleaned - to remove impregnated pyrolysis aerosols - with inexpensive chemicals following straight forward methodologies (Nascimento et al., 2017).

Considering these advantages, several researchers have shown interest in utilizing char. Shang et al. (2012) tested the char from the pyrolysis of camphor tree as $\mathrm{H}_{2} \mathrm{~S}$ adsorbent. The surface properties of the char were characterized using $\mathrm{pH}$ and Fourier-transform infrared spectroscopy (FTIR). Both $\mathrm{pH}$ and FTIR showed that carboxylic and hydroxide radical groups were responsible for the adsorption, where the adsorption capacity ranged from 1.2 to $121.4 \mathrm{mg} / \mathrm{g}$. Bagreev et al. (2001) pyrolyzed sewage-sludgederived fertilizer impregnated with zinc chloride. The char was washed with hydrochloric acid to remove the excess zinc chloride and other soluble chlorides and, then, it was tested in the adsorption of $\mathrm{H}_{2} \mathrm{~S}(0.3 \% \mathrm{v} / \mathrm{v})$ from moist air. The treatment with hydrochloric acid increased the porosity of the char greatly. The authors also reported that due to the large quantities of inorganic oxides and salts, $\mathrm{H}_{2} \mathrm{~S}$ underwent surface reactions and was left on the surface in the form of nonvolatile sulfides and sulfates. The reported breakthrough capacity ranged from 3 to $52 \mathrm{mg} / \mathrm{g}$.

Instead of pyrolysis, Ros et al. (2006) opted for the gasification of sewage sludge. The experiments with the char were carried out under a mixture of air and $\mathrm{H}_{2} \mathrm{~S}\left(1 \% \mathrm{H}_{2} \mathrm{~S}\right)$ as well. Oxidation played an important role in the $\mathrm{H}_{2} \mathrm{~S}$ removal. The specific $\mathrm{H}_{2} \mathrm{~S}$ removal capacities ranged from 1.5 to $131 \mathrm{mg} / \mathrm{g}$. $\mathrm{Xu}$ et al. (2014) compared the performances of chars from sewage sludge and pig manure under air $\left(1 \% \mathrm{H}_{2} \mathrm{~S}\right)$. The authors emphasized the effect of strong alkalinity and rich minerals on the sorption of $\mathrm{H}_{2} \mathrm{~S}$. The catalytic conversion to elemental $\mathrm{S}^{\circ}$ (mainly occurred in the char pores) and $\mathrm{SO}_{4}^{2-}$ (on the char surface) was the main route for $\mathrm{H}_{2} \mathrm{~S}$ removal. Sun et al. (2016) enhanced the properties of chars from sewage sludge via carbonization. Commercial activated carbon was also tested. The authors reported that the adsorption capacity of the chars ranged from 10 to $70 \mathrm{mg} / \mathrm{g}$ under moist air. The degree of heterogeneity on the surface of the char showed to be far more than that of the activated carbon. The chars outperformed the activated carbon $(20 \mathrm{mg} / \mathrm{g})$, despite the limited textural properties.

In this context, the present work is aimed at testing chars from the pyrolysis of sewage sludge, under nitrogen, as hydrogen sulfide adsorbents and comparing their performances against that of activated carbon, which was impregnated with iron to emulate the same composition and properties of the chars. The influence of chemical agents $(\mathrm{HCl}$ or $\mathrm{KOH})$ on the textural properties of the chars was also investigated. The experiments were carried out in a fixed-bed column and were modeled by a system of differential equations. Adsorption parameters were estimated, and the results discussed.

\section{METHODOLOGY}

\subsection{Preparation and characterization of the chars}

The chars used in this work were obtained from the fast pyrolysis of sewage sludge under nitrogen using a rotating cylinder reactor, see Pedroza et al. 
(2014) for details. Pyrolysis chars usually adsorb bio-oil (aerosols to be exact) that remain impregnated after reaction. For the chars to be used as adsorbents, the aerosols must be removed, and for this, dichloromethane (99.5\%) and hydrated ethanol are efficient, as reported by Nascimento et al. (2017). After washing the char, three different samples were prepared. The first one underwent physical activation only, which was performed under $1 \mathrm{~mL} / \mathrm{min}$ of nitrogen for 2 hours, in an oven at $700^{\circ} \mathrm{C}$. This sample was named $\mathrm{CA}_{\text {Fis. }}$. The second and third samples were activated chemically with $\mathrm{KOH}(3 \mathrm{M})$ or $\mathrm{HCl}(7.5 \mathrm{M})$, and were named $\mathrm{CA}_{\mathrm{KOH}}$ and $\mathrm{CA}_{\mathrm{HCl}}$, respectively. The chemical activation was performed by adding $10 \mathrm{~g}$ of char to $50 \mathrm{~mL}$ of $\mathrm{KOH}$ (or $\mathrm{HCl}$ ) under stirring for 2 hours, followed by vacuum filtration and then physical activation under $1 \mathrm{~mL} / \mathrm{min}$ of nitrogen at $500{ }^{\circ} \mathrm{C}$. The $\mathrm{pH}$ was brought back to neutrality by washing the samples with distilled water, which was removed by drying in an oven at $100^{\circ} \mathrm{C}$ for 24 hours.

Commercial activated carbon $\left(d_{p}=77.24 \mu m\right)$ was used as reference to compare the performance of the chars against that of a wellknown material. Since sewage sludge chars contain inorganic materials, the activated carbon composition was modified via impregnation, using iron nitrate $\left(30 \% \mathrm{Fe}_{2} \mathrm{O}_{3}\right)$ as precursor, so that all samples had similar quantities of iron. After the impregnation, the activated carbon underwent drying at $100^{\circ} \mathrm{C}$ for 12 hours. This particular sample was named $\mathrm{CC}_{\mathrm{Fe}}$.

After preparation, the four samples were characterized via X-ray Diffraction utilizing an XRD model 7000 using $\mathrm{Cu} K \alpha$ radiation $\left(1.542 \times 10^{-10} \mathrm{~m}\right)$. The crystallographic cards used to identify the phases were from The International Center for Diffraction Data - ICDD. The program X'Pert HighScore Plus was used to do the searches.

X-ray Fluorescence was performed under Argon using a Shimadzu EDX-720/800HS for the content of inorganic materials only. The elemental analysis, that is commonly used to access the contents of carbon, hydrogen, nitrogen, and oxygen, was not conducted in this work.

Scanning Electron Microscopy was performed using a Zeiss analyzer, model Auriga, equipped with a high efficiency electron detector.

The specific area was determined by the BET method (Brunauer-Emmett-Teller) via adsorption of $\mathrm{N}_{2}$ at $77 \mathrm{~K}$. The measurements were carried out in a Micromeritics ASAP 2020. The pore volume and average pore size were determined by the $\mathrm{BJH}$ method (Barret-Joyner-Halenda).

The particle size distribution was also assessed using a CILAS laser particle analyzer. Before each run, the samples were dried in oven at $100^{\circ} \mathrm{C}$ for 2 hours to keep the moisture low.

\subsection{Dynamic adsorption of $\mathrm{H}_{2} \mathrm{~S}$}

Figure 1 shows the experimental apparatus used to evaluate the adsorption capacity of the sewage sludge pyrolysis chars and the activated carbon impregnated with iron. The apparatus consists of a fixed-bed column, gas cylinders, a flowmeter, a gas collector, and an analysis kit.

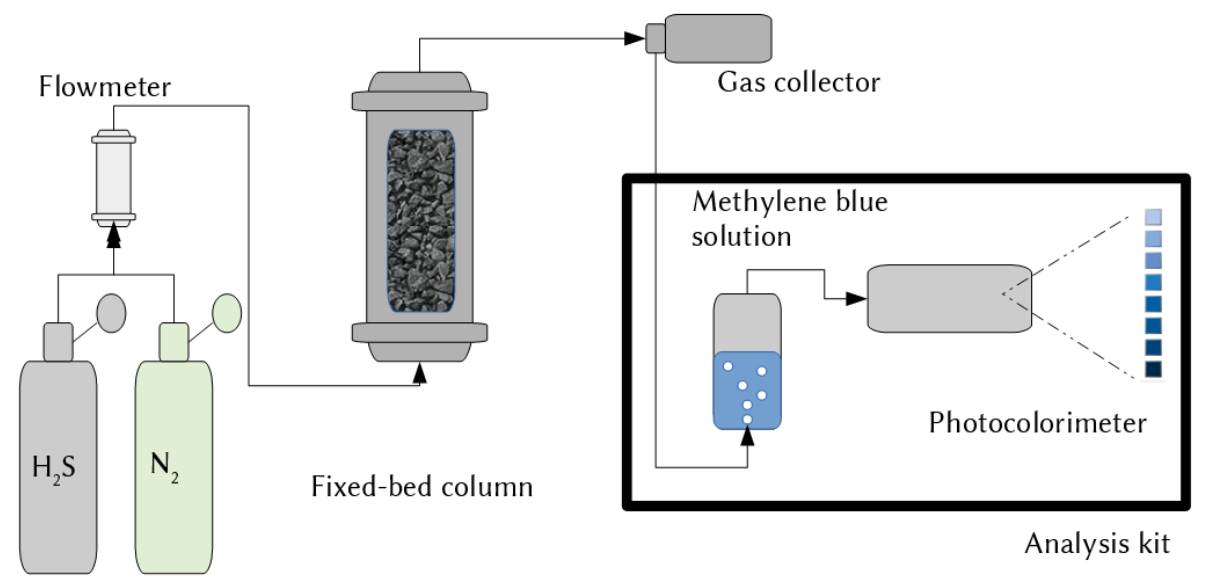

Figure 1. Experimental apparatus used in the dynamic adsorption of $\mathrm{H}_{2} \mathrm{~S}$. 
The experiments were carried out at $25^{\circ} \mathrm{C}$ and 1 atm. The fixed bed of adsorbent (18.24 g) was held in place by a set of perforated plates that was designed to evenly distribute the gas flow (50 $\mathrm{mL} / \mathrm{min}$ ) across the column (i.d. of $4 \mathrm{~cm}$ and $20 \mathrm{~cm}$ in length). The gas flowmeter was from Varian Analytical Instruments. Nitrogen was used to purge the system before and after the runs. Hydrogen sulfide (600 ppm) was provided by Linde Brazil, and its composition was about the same as that of biogas.

The composition of the effluent gas was measured following the methylene blue methodology, which consists in bubbling the gas through a methylene blue solution prior to actual analysis by photocolorimetry. It is a method for quantifying hydrogen sulfide that was created in the 1950s and has been perfected since then, as reported by Reese et al. (2011) and Li (2015). The methylene blue method used a kit model KBA0137 developed by EMBRAPA in partnership with AlfaKit, two Brazilian companies. The kit had the capability of holding $500 \mathrm{~cm}^{3}$ of gas and was specified to quantify hydrogen sulfide from 20 to $610 \mathrm{ppm}$ reliably, see i.e. Catapan et al. (2011), Zilotti (2012), and Antonelli et al. (2016).

The breakthrough curves were plotted from hydrogen sulfide concentration readings, taken every 15 minutes until the bed of char was saturated, which was evinced when concentrations of influent and effluent gases were the same.

\subsubsection{Mass Transfer Zone (MTZ)}

The performance of a column is related to the length and shape of the mass transfer zone (MTZ) that develops during adsorption. Thus, the MTZ represents the concentration gradient of the adsorbate ranging from zero (5\% of the feed concentration and, where the adsorbate concentration begins to increase and be detected at the outlet) to the equilibrium concentration (95\% of the feed concentration, where the outlet concentration is equal to the feed/inlet concentration). This is the part of the bed where mass transfer is intensified (Guo et al., 2007). The time to start the MTZ formation depends on several factors such as the resistance in the gas film surrounding the solid, nature and composition of the adsorbent, temperature, and gas flow rate.

The length of transfer zone in the bed can be estimated by Equation 1 (Guo et al., 2007):

$$
L_{M T Z}=\frac{L\left(\tau_{0.95}-\tau_{0.05}\right)}{\left(\tau_{0.95}+\tau_{0.05}\right) / 2}
$$

Where $\tau$ is the time (min) when the $\mathrm{H}_{2} \mathrm{~S}$ concentration corresponds to 5 or $95 \%$ of the feed concentration.

The length $L$ of the adsorbent bed is calculated by Equation 2:

$L=\frac{(m)_{a d s}}{\frac{\pi D^{2}}{4} \rho_{P}\left(1-\varepsilon_{b}\right)}$

Where $D$ is the diameter of the bed.

\subsubsection{Adsorption capacity evaluation}

The adsorption capacity at breakthrough time $\left(C / C_{o}=0.05\right)$ can be defined by Equation 3:

$q_{R}=\frac{C_{0} t_{R} Q}{m_{a d s}}$

\subsubsection{Maximum adsorption capacity evaluation}

The maximum adsorption capacity $q_{m}$ of the adsorbent $\left(\mathrm{mgH}_{2} \mathrm{~S} / \mathrm{g}_{\text {ads }}\right)$ can be calculated by Equation 4 (Xiao et al., 2008).

$q_{m}=\frac{34 C_{0} Q}{1000 m_{\text {ads }}} \int_{0}^{t_{e q}}\left(1-\frac{C_{t}}{C_{0}}\right) d t$

Where $C_{o}$ is the initial concentration of the adsorbate $\left(\mathrm{mol} / \mathrm{m}^{3}\right) ; Q$ is the flow rate of the gas phase $\left(\mathrm{m}^{3} / \mathrm{min}\right) ; m_{a d s}$ is the adsorbent mass $(\mathrm{g}) ; t_{e q}$ is the time to reach the equilibrium concentration (min), and the integral $\int_{0}^{t_{e q}}\left(1-C_{t} / C_{0}\right)$ represents the area $(\mathrm{min})$ above the breakthrough curve.

\subsection{Dynamic adsorption modeling}

The model used to describe the adsorption was based on the system of equations used by Lessa (2012), which is essentially a mass balance for the gas and particle phases, considering the following assumptions:

a) Adsorption occurs isothermally;

b) Plug flow model with axial dispersion applies;

c) Mass transfer rate is constant; 
d) Adsorbent particles are spherical and homogeneous in size and density;

e) The gas phase behaves as an ideal mixture;

f) There is no radial gradient concentration;

g) Porosity and tortuosity factor of the particle are constant;

h) Mass transfer occurs both in the film around the particle (characterized by the mass transfer coefficient) as well as in the particle (characterized by the effective diffusivity).

The mass balance of the gas phase is represented by:

$\frac{\partial C(z, t)}{\partial t}=D_{L} \cdot \frac{\partial^{2} C(z, t)}{\partial z^{2}}-V \cdot \frac{\partial C(z, t)}{\partial z}-$

$-\frac{\left(1-\varepsilon_{b}\right)}{\varepsilon_{b}} \cdot \frac{3}{R_{p}} \cdot k_{S}\left[C(z, t)-C_{P R}(z)\right]$

with the initial condition that the concentration of the fluid phase is zero:

$C(z, 0)=0$

The boundary conditions at the bottom and top of the fixed bed column are as follows:

$-\left.D_{L} \cdot \frac{\partial C(z, t)}{\partial z}\right|_{z=0}=V \cdot\left[C(0, t)-C_{i}\right]$

$\left.\frac{\partial C(z, t)}{\partial z}\right|_{z=L}=0$

Where $\varepsilon_{\mathrm{b}}$ is the porosity of the bed; $C$ is the gas concentration in the gas phase $\left(\mathrm{mol} / \mathrm{dm}^{3}\right) ; C_{P R}$ is the concentration of the gas as a function of the bed length $(\mathrm{mol} / \mathrm{dm})$ and time $t(\mathrm{~min}) ; C_{i}$ is the feed concentration $\left(\mathrm{mol} / \mathrm{dm}^{3}\right) ; D_{L}$ is the coefficient of axial diffusivity in the bed $\left(\mathrm{dm}^{2} / \mathrm{min}\right) ; v$ is the surface velocity $(\mathrm{dm} / \mathrm{min}) ; k_{s}$ is the external mass transfer coefficient $(\mathrm{dm} / \mathrm{min}) ; z$ is the axial coordinate $(\mathrm{dm}) ; L$ is the bed length $(\mathrm{dm})$; and $R p$ is the radius of the particle $(\mathrm{dm})$.

The mass balance in the particle phase is represented by:

$$
\begin{aligned}
& \varepsilon_{p} \cdot \frac{\partial C_{p}(r, z, t)}{\partial t}+\rho_{p} \cdot \frac{\partial q_{e}(z, t)}{\partial t}= \\
& =\varepsilon_{p} \cdot D_{e} \cdot\left[V \cdot \frac{\partial^{2} C_{p}(r, z, t)}{\partial r^{2}}+\frac{2}{r} \cdot \frac{\partial C_{p}(r, z, t)}{\partial r}\right]
\end{aligned}
$$

that is subject to the following initial condition, which states that the concentration in the particle is zero at $t=0$ :

$C_{p}(r, z, 0)=0$

The boundary conditions are as follows:

$\left.\frac{\partial C_{p}(r, z, t)}{\partial r}\right|_{r=0}=0$

$$
\begin{aligned}
& \left.\varepsilon_{p} \cdot D_{e} \cdot \frac{\partial C_{p}(r, z, t)}{\partial r}\right|_{r=R_{p}}= \\
& =k_{S} \cdot\left[C(z, t)-C_{P R}(z)\right]
\end{aligned}
$$

Where $D_{e}$ is the effective diffusivity $\left(\mathrm{dm}^{2} / \mathrm{min}\right) ; r$ is the radial coordinate $(\mathrm{dm}) ; \varepsilon_{\mathrm{p}}$ is the porosity of the particle; $C_{P}$ is the gas concentration inside the particle $\left(\mathrm{mol} / \mathrm{dm}^{3}\right)$; and $\rho_{\mathrm{p}}$ is the density of the particle $\left(\mathrm{g} / \mathrm{dm}^{3}\right)$.

In Equation 9, $d q_{e}(z, t) / d t$ is obtained by taking the derivative of the Langmuir equilibrium model (concentration of $\mathrm{H}_{2} \mathrm{~S}$ in the particle in equilibrium with the fluid phase), represented by:

$q_{e}=\frac{\left.q_{m} \cdot b \cdot C_{p}\right)}{1+b \cdot C_{p}}$

$q_{m}$ is the maximum adsorption capacity $\left(\mathrm{mol} / \mathrm{dm}^{3}\right)$, $b$ is the theoretical adsorption capacity in the monolayer $\left(\mathrm{dm}^{3} / \mathrm{mol}\right)$.

Deriving Equation 13 as a function of $C_{p}$ and replacing in Equation 9:

$$
\begin{aligned}
& \varepsilon_{p} \cdot \frac{\partial C_{p}(r, z, t)}{\partial t}+ \\
& +\rho_{p} \cdot \frac{q_{m} \cdot b}{\left(1+b C_{p}(r, z, t)\right)^{2}} \frac{\partial C_{p}(r, z, t)}{\partial t}= \\
& =\varepsilon_{p} \cdot D_{e} \cdot\left[V \cdot \frac{\partial^{2} C_{p}(r, z, t)}{\partial r^{2}}+\frac{2}{r} \cdot \frac{\partial C_{p}(r, z, t)}{\partial r}\right]
\end{aligned}
$$

The mathematical model formed by the partial differential equations system (Eqs. 9 and 14) was 

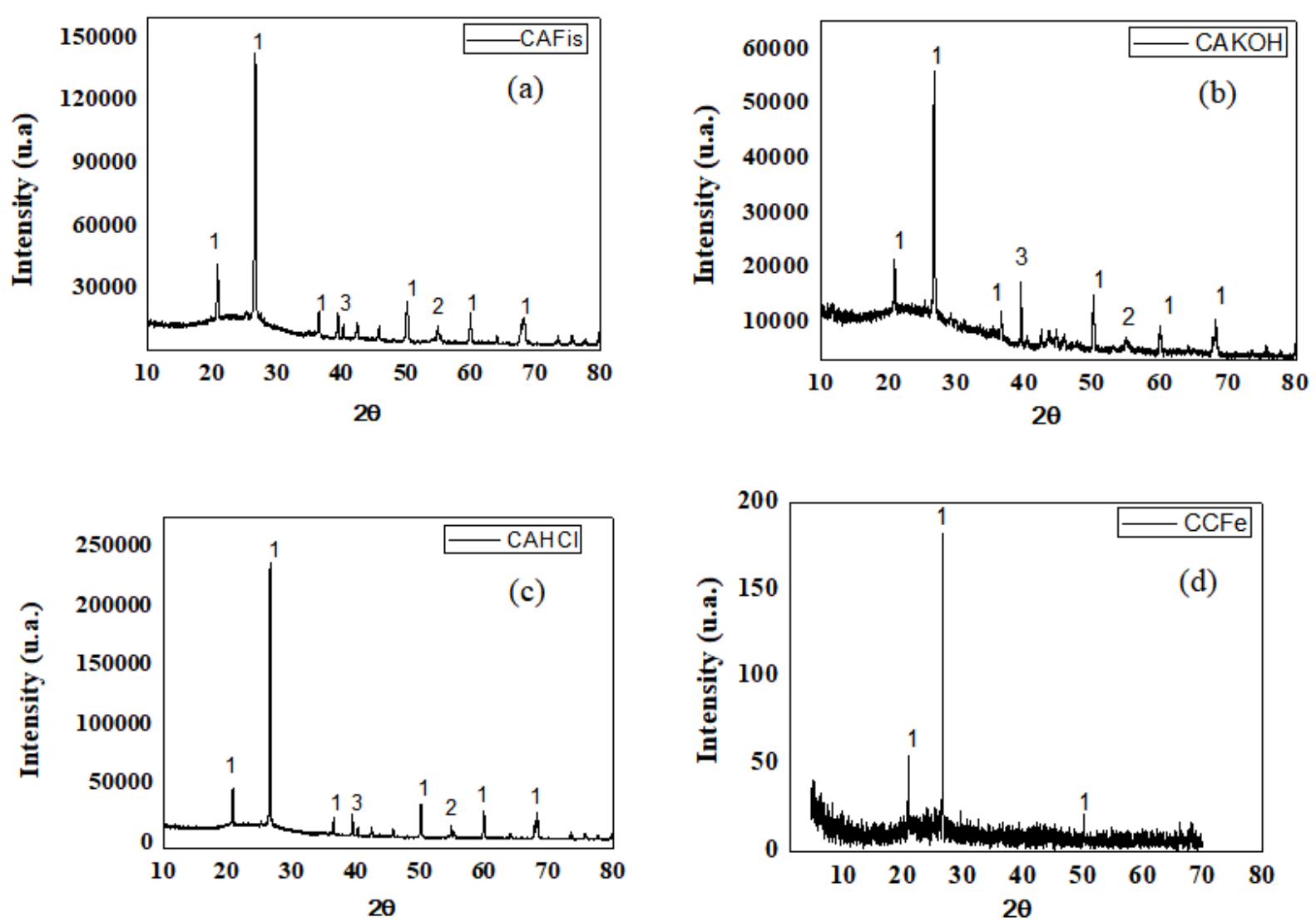

Figure 2. X-ray diffraction patterns of the sewage sludge chars. (a) is the physically activated char, (b) is char activated with $\mathrm{KOH},(\mathrm{c})$ is the char activated with $\mathrm{HCl}$, and (d) is the activated carbon. The phases are: 1 - Quartz, 2 Caolinite, and 3 - Microline.

transformed into a system of ordinary differential equations using the method of lines of discretization, and was then solved numerically using the DASSL solver and an optimization algorithm to estimate the axial diffusivity $\left(D_{L}\right)$, the intraparticle effective diffusivity $\left(D_{e}\right)$, and the external mass transfer coefficient $\left(k_{s}\right)$.

\section{RESULTS AND DISCUSSION}

\subsection{Characteristics of the char samples}

\subsubsection{XRD analysis}

Figure 2 shows the $\mathrm{X}$-ray Diffractograms of the sewage sludge char and the activated carbon that was impregnated with iron. It is observed that there is little crystallinity present in the chars, and it is due to ash, the main residue of the degradation of carbonaceous materials. Char ashes are mainly composed of silica, aluminum, iron, potassium, and calcium, elements that belong to quartz, microline, and kaolinite. Figure 2a refers to the physically activated sludge char. In this case, only quartz was found. Fig. 2.b and Fig. $2 \mathrm{c}$ refer to chars activated with $\mathrm{KOH}$ and $\mathrm{HCl}$, respectively. They show very similar spectra and indicate the presence of kaolinite and microline, as well as a high intensity of quartz at $28^{\circ}$. Figure $2 d$, like Figure $2 \mathrm{a}$, shows the presence of quartz only. Vianna (2013) reported similar patterns. The author reported the presence of dolomite $(\mathrm{CaO}, \mathrm{MgO}$, and $\left.\mathrm{CO}_{2}\right)$ and kaolinite $\left(\mathrm{Al}_{2} \mathrm{O}_{3}, \mathrm{SiO}_{2}\right.$, and $\left.\mathrm{H}_{2} \mathrm{O}\right)$ in small quantities. Differences such as these may be related to the conditions under which the char was produced.

\subsubsection{SEM analysis}

The SEM micrographs of the four samples are shown in Figure 3. The morphological analysis allowed the identification of irregular surfaces, with small particles $(33.18 \mu \mathrm{m}$, according to the granulometric analysis), of different shapes and sizes. 


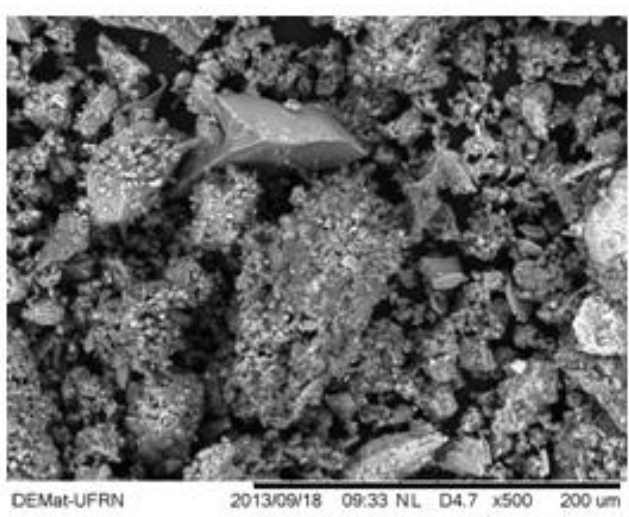

$\left(\mathrm{CA} A_{\mathrm{Fis}}\right)$

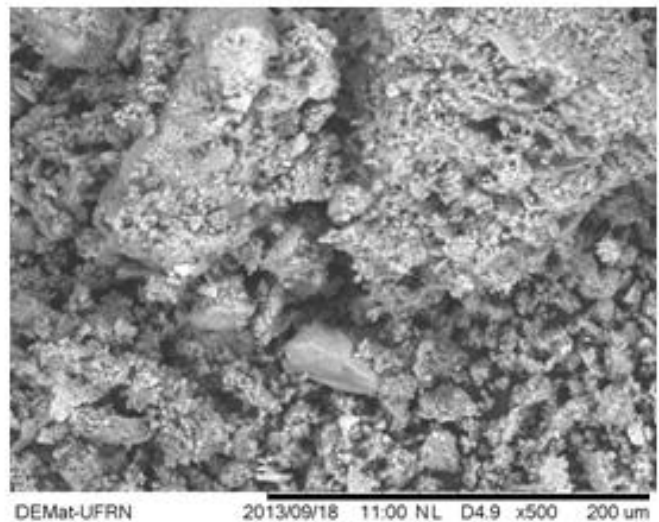

$\left(\mathrm{CA}_{\mathrm{HCl}}\right)$

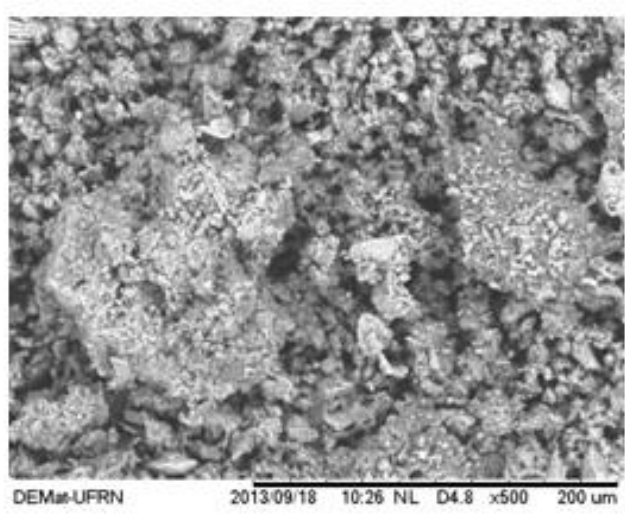

(CAKOH)

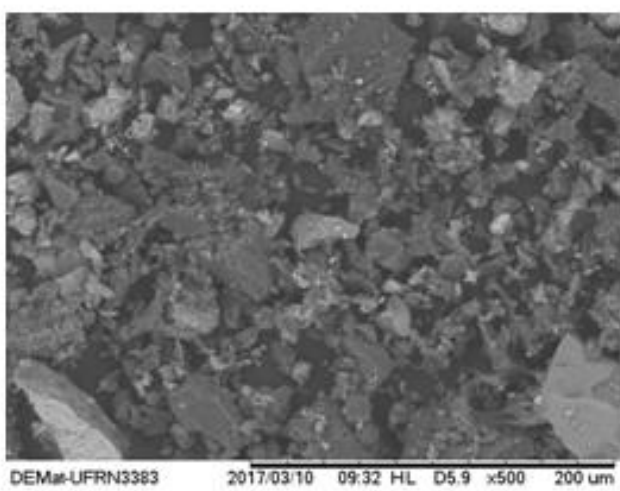

$\left(\mathrm{CC}_{\mathrm{Fe}}\right)$

Figure 3. SEM micrographs (magnification of $\mathrm{x} 500$ ) of the samples $\mathrm{CA}_{\mathrm{Fis}}, \mathrm{CA}_{\mathrm{KOH}}, \mathrm{CA}_{\mathrm{HCl}}$, and $\mathrm{CC}_{\mathrm{Fe}}$.

\subsubsection{Textural characteristics}

Table 1 presents the textural characteristics of the samples with respect to the specific area, total pore volume, and average pore size, calculated from $\mathrm{N}_{2}$ isotherms at $77 \mathrm{~K}$.

The results show that the specific area and the pore volume of the sewage sludge char increased for both samples subjected to chemical activation, especially the one treated with $\mathrm{HCl}$. This shows the efficiency of the activating agents. The specific area of the activated carbon impregnated with iron also increased considerably.

The results found are consistent with those reported in the literature. Wu et al. (2013) reported a specific area of $287 \mathrm{~m}^{2} / \mathrm{g}$ for sewage sludge char activated with $\mathrm{KOH}$. Although the activation with chemical agents improves the textural characteristics of chars, the nature of the biomass and the conditions under which the pyrolysis was carried out also affected porosity and other properties (Li et al., 2011).

Table 1. Textural characteristics of the samples.

\begin{tabular}{cccc}
\hline & $\begin{array}{c}\text { Specific area } \\
\left(\mathbf{m}^{\mathbf{2}} \mathbf{g}\right)\end{array}$ & Pore volume $\left(\mathbf{c m}^{\mathbf{3}} \mathbf{\mathbf { g }}\right)$ & $\begin{array}{c}\text { Average pore } \\
\text { size }(\AA)\end{array}$ \\
\hline $\mathrm{CA}_{\mathrm{Fis}}$ & 88 & 0.060 & 27.16 \\
$\mathrm{CA}_{\mathrm{KOH}}$ & 122 & 0.075 & 24.60 \\
$\mathrm{CA}_{\mathrm{HCl}}$ & 248 & 0.185 & 29.94 \\
$\mathrm{CC}_{\mathrm{Fe}}$ & 455 & 0.219 & 22.07 \\
\hline
\end{tabular}


Table 2. Textural characteristics of the samples.

\begin{tabular}{c|cccccc}
\hline & $\mathbf{C}_{\text {as-is }}$ (\%) & $\mathbf{C L}_{\text {dicl. }}$ (\%) & $\mathbf{C A}_{\text {Fis }}(\%)$ & $\mathbf{C A}_{\text {KоH }}(\%)$ & $\mathbf{C A}_{\text {HCl }}(\%)$ & $\mathbf{C C}_{\text {Fe }}(\%)$ \\
\hline $\mathrm{Fe}_{2} \mathrm{O}_{3}$ & 60.56 & 39.95 & 35.89 & 35.63 & 29.47 & 35.26 \\
$\mathrm{SiO}_{2}$ & 9.19 & 26.41 & 39.94 & 26.04 & 41.32 & 11.15 \\
$\mathrm{SO}_{3}$ & 7.36 & 10.03 & 8.39 & 13.42 & 10.74 & - \\
$\mathrm{CaO}$ & 3.77 & 1.87 & 0.54 & 3.78 & 1.74 & 1.53 \\
$\mathrm{TiO}_{2}$ & 1.88 & 1.58 & 6.03 & 1.65 & 5.85 & 0.8 \\
$\mathrm{P}_{2} \mathrm{O}_{5}$ & 1.68 & 3.67 & 0.53 & 3.54 & 1.19 & 0.8 \\
$\mathrm{ZrO}_{2}$ & 0.19 & 0.53 & 3.86 & 0.26 & 0.72 & - \\
$\mathrm{ZnO}_{\mathrm{Al}_{2} \mathrm{O}_{3}}$ & 1.11 & 0.63 & 0.44 & 0.52 & 0.53 & - \\
$*$ & 12.76 & 14.15 & 2.78 & 13.96 & 6.01 & - \\
\hline
\end{tabular}

${ }^{*} \mathrm{~K}_{2} \mathrm{O}, \mathrm{Cr}_{2} \mathrm{O}_{3}, \mathrm{CuO}, \mathrm{NiO}, \mathrm{MnO}$, and $\mathrm{SrO}$

According to IUPAC (1985), the chars used in this work are classified as mesoporous because they have pore volumes ranging from 0.02 to 0.1 $\mathrm{cm}^{3} / \mathrm{g}\left(\mathrm{CA}_{\text {Fis }}\right.$ and $\mathrm{CA}_{\text {KOH }}$ ranged from 0.060 to 0.075 $\mathrm{cm}^{3} / \mathrm{g}$ ), and micropores with volumes from 0.15 to $0.5 \mathrm{~cm}^{3} / \mathrm{g}$. In the cases of $\mathrm{CC}_{\mathrm{Fe}}$ and $\mathrm{CA}_{\mathrm{HCl}}$, the volumes varied from 0.185 to $0.219 \mathrm{~cm}^{3} / \mathrm{g}$.

\subsubsection{XRF analysis}

Table 2 presents the results of the XRF analysis of the sewage sludge char sample as is $\left(C_{a s-i s}\right)$, the char washed with dichloromethane $\left(\mathrm{CL}_{\text {dicl }}\right)$, the char activated physically $\left(\mathrm{CA}_{\mathrm{Fis}}\right)$, the char activated with $\mathrm{KOH}\left(\mathrm{CA}_{\mathrm{KOH}}\right)$, the char activated with $\mathrm{HCl}\left(\mathrm{CA}_{\mathrm{HC}}\right)$, and the activated carbon impregnated with iron $\left(\mathrm{CC}_{\mathrm{Fe}}\right)$.

According to Table 2, the sewage sludge char presents high amounts of $\mathrm{Fe}_{2} \mathrm{O}_{3}$, followed by other main oxides, such as $\mathrm{SiO}_{2}, \mathrm{Al}_{2} \mathrm{O}_{3}, \mathrm{SO}_{3}$, and $\mathrm{CaO}$. The iron available in the sewage sludge char is in the form of iron oxide III. Pedroza et al. (2017) reported that the presence of this metal is due to the nature of the physicochemical treatments that the sewage sludge received at the effluent treatment stations. The reduction in composition for most of the oxides found in the char treated with dichloromethane compared to char as received $\left(C_{a s-i s}\right)$, was probably caused by leaching during the successive washings.

\subsection{Dynamic adsorption of $\mathrm{H}_{2} \mathrm{~S}$}

The dynamic adsorption of $\mathrm{H}_{2} \mathrm{~S}$ allowed the evaluation of the adsorption on the adsorbent samples in a fixed-bed column, the breakthrough time $\left(C / C_{o}=0.05 \%\right)$, as well as the bed saturation time $\left(C / C_{o}=0.95 \%\right)$. The general pattern of the breakthrough curves (Figure 4) was expected for the samples under investigation: $\mathrm{CA}_{\mathrm{Fis}}, \mathrm{CA}_{\mathrm{KOH}}, \mathrm{CA}_{\mathrm{HCl}}$, and $\mathrm{CC}_{\mathrm{Fe}}$.

The behavior of the curve for the activated carbon $\left(\mathrm{CC}_{\mathrm{Fe}}\right)$ shows a steep slope in comparison to the other curves. According to Nascimento et al.
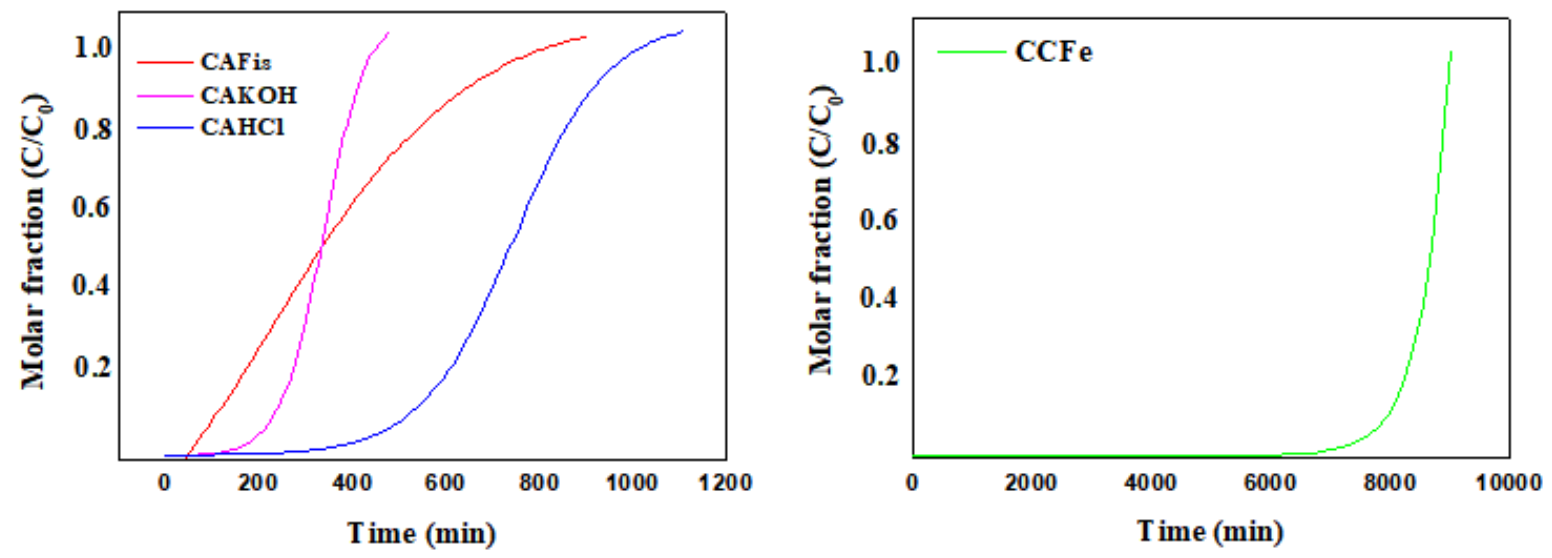

Figure 4. Dynamic adsorption of $\mathrm{H}_{2} \mathrm{~S}$ on $\mathrm{CA}_{\mathrm{Fis}}, \mathrm{CA}_{\mathrm{KOH}}, \mathrm{CA}_{\mathrm{HCl}}$, and $\mathrm{CC}_{\mathrm{Fe}}$. 
(2014), the steeper the curve, the greater the resistance to mass transfer is.

Table 3 summarizes the analysis performed on each curve: the breakthrough $\left(t_{R}\right)$ and equilibrium $\left(t_{e q}\right)$ times, the area above the breakthrough curve $\left(A_{b c}\right)$, the length of the mass transfer zone $\left(L_{M T Z}\right)$, and the percentage of $\mathrm{H}_{2} \mathrm{~S}$ adsorbed, all under the operating conditions based on the ratio of the area above the curves to the difference between the breakthrough and equilibrium times, the adsorption capacity at breakthrough time $\left(q_{R}\right.$, evaluated by Equation 3), and the maximum adsorption amount of $\mathrm{H}_{2} \mathrm{~S}$ per gram of adsorbent $\left(q_{m}\right.$, evaluated by Equation 4).

It can be seen that the breakthrough time, the equilibrium, and the area under the breakthrough curve increase in the following order: $\mathrm{CC}_{\mathrm{Fe}}>\mathrm{CA}_{\mathrm{HCl}}>$ $\mathrm{CA}_{\mathrm{KOH}}>\mathrm{CA}_{\mathrm{Fis}}$. The percentage of adsorption, the adsorption capacity at breakthrough time as well as the maximum adsorption capacity is higher for the activated carbon $\left(\mathrm{CC}_{\mathrm{Fe}}\right)$. This sample had higher specific area and total pore volume, which evinces that the iron increased the performance of this adsorbent. It should also be noted that the pore size of the $\mathrm{CC}_{\mathrm{Fe}}$ was lower than the values found for the other samples. This is because the $\mathrm{CC}_{\mathrm{Fe}}$ was not treated with $\mathrm{KOH}$ or $\mathrm{HCl}$. The physically activated sewage sludge char samples presented the lowest performance in comparison to the other samples, showing the importance of the treatment using these chemical agents. Thus, the $\mathrm{CC}_{\mathrm{Fe}}$ sample was more efficient in terms of capture of $\mathrm{H}_{2} \mathrm{~S}$ and more complete in terms of desorption.

The $\mathrm{HCl}$ led the sewage sludge char to have low $\mathrm{L}_{\mathrm{MTZ}}(5.72 \mathrm{~cm})$, long breakthrough time, high adsorption capacity $\left(q_{R}\right)$, and high maximum adsorption capacity $\left(q_{m}\right)$. Nevertheless, the low percentage of adsorption (47.67\%) obtained for
$\mathrm{CA}_{\mathrm{HCl}}$ can probably be explained by the low percentage of $\mathrm{Fe}_{2} \mathrm{O}_{3}$, which may also have been removed during activation.

The adsorption capacities $\left(q_{R}\right)$ for all the samples at breakthrough time were higher than the maximum adsorption capacity $\left(q_{m}\right)$. According to Castrillon et al. (2016) and Menezes (2017), this is an indication that physical adsorption is predominant. It is also important to emphasize that during activation; all chemical agents were removed to avoid any possible reaction.

Among the pyrolysis chars, the highest $q_{R}$ value was $657.60 \mathrm{mgH}_{2} \mathrm{~S} / \mathrm{g}_{\text {ads }}$ for $\mathrm{CA}_{\mathrm{HCl}}$, with $\mathrm{C}_{\mathrm{H} 2 \mathrm{~S}}=600$ $\mathrm{ppm}$, and $t=400 \mathrm{~min}$. Abdullah et al. (2017) tested kaolin in the adsorption of hydrogen sulfide (initial concentration of $50 \mathrm{ppm}$ ) and found that, at breakthrough time, the adsorption capacity was $56 \times 10^{-3} \mathrm{mgH}_{2} \mathrm{~S} / \mathrm{g}_{\text {ads }}(t=11 \mathrm{~min})$. It is noteworthy that the kaolin was composed of $\mathrm{SiO}_{2}(70.08 \%)$, $\mathrm{Al}_{2} \mathrm{O}_{3}$ (21.41\%), and $\mathrm{Fe}_{2} \mathrm{O}_{3}$ (0.55\%). Moreover, other oxides of different nature $(\mathrm{MgO} 4.74 \%$ and $\mathrm{K}_{2} \mathrm{O} 2.72 \%$ ) that are present in the samples of this work may also have an influence on the adsorption capacity.

Other researchers have found maximum adsorption capacities that are in the same order of magnitude as those presented in this work. Garcia (2014) used dry sludge to capture $\mathrm{H}_{2} \mathrm{~S}$ (100-500 ppm). The conditions reported are $\mathrm{pH}=6.81-6.86$, temperature from 32 to $34.6^{\circ} \mathrm{C}$, and gas flow rate ranging from 2.2 to $4.03 \mathrm{~L} / \mathrm{min}$. The maximum adsorption capacity ranged from $3.3 \times 10^{-5}$ to $2.54 \times 10^{-3} \mathrm{mgH}_{2} \mathrm{~S} / \mathrm{g}_{\text {ads }}$. Ros et al. (2006) tested chars from dry and wet sewage sludge. One of the samples presented low porosity and, therefore, low carbon content. The adsorption capacity of these materials varied from 0 to $18 \mathrm{mgH}_{2} \mathrm{~S} / \mathrm{g}_{\text {ads }}$. When these materials were activated under inert

Table 3. Adsorption parameters obtained for the sewage sludge chars and the activated carbon.

\begin{tabular}{cccccccc}
\hline & $\begin{array}{c}\mathbf{t}_{\mathrm{R}} \\
(\mathbf{m i n})\end{array}$ & $\begin{array}{c}\mathbf{t}_{\mathrm{eq}} \\
(\mathbf{m i n})\end{array}$ & $\begin{array}{c}\mathbf{A}_{\mathrm{bc}} \\
(\mathbf{m i n})\end{array}$ & $\begin{array}{c}\mathrm{L}_{\mathrm{MTZ}} \\
(\mathbf{c m})\end{array}$ & $\begin{array}{c}\mathbf{H}_{\mathbf{2}} \mathbf{S} \\
\text { Adsorbed } \\
(\mathbf{\%})\end{array}$ & $\begin{array}{c}\boldsymbol{q}_{\boldsymbol{R}} \\
\left(\mathbf{m g H} \mathbf{H}_{\mathbf{2}} \mathbf{S} / \mathbf{g}_{\text {ads }}\right)\end{array}$ & $\begin{array}{c}\boldsymbol{q}_{\mathbf{m}} \\
\left(\mathbf{m g H} \mathbf{H}_{\mathbf{2}} \mathbf{S} / \mathbf{g}_{\text {ads }}\right)\end{array}$ \\
\hline $\mathbf{C A}_{\mathrm{Fis}}$ & 90 & 390 & 130.12 & 9.6 & 43.36 & 148.02 & 7.20 \\
$\mathbf{C A}_{\text {KOH }}$ & 180 & 420 & 141.71 & 5.78 & 59.04 & 296.00 & 7.90 \\
$\mathbf{C A}_{\mathrm{HCl}}$ & 400 & 1020 & 295.56 & 5.72 & 47.67 & 657.60 & 16.52 \\
$\mathbf{C C}_{\mathrm{Fe}}$ & 7620 & 9000 & 954.33 & 1.32 & 69.15 & $12,527.80$ & 53.04 \\
\hline
\end{tabular}


Table 4. Parameters used in the modeling of the dynamic adsorption of $\mathrm{H}_{2} \mathrm{~S}$ on chars.

\begin{tabular}{cccccccc}
\hline$C_{o}\left(\mathbf{m o l} / \mathrm{dm}^{3}\right)$ & $v(\mathrm{dm} / \mathrm{min})$ & $L(\mathrm{dm})$ & $\rho_{\mathrm{b}}\left(\mathrm{g} / \mathrm{dm}^{\mathbf{3}}\right)$ & $\rho_{\mathrm{p}}\left(\mathrm{g} / \mathrm{dm}^{\mathbf{3}}\right)$ & $\mathrm{R}_{\mathrm{p}}(\mathrm{dm})$ & $\varepsilon_{\mathrm{b}}$ & $\varepsilon_{\mathrm{p}}$ \\
0.0176 & 0.398 & 2.0 & 555.5 & 72.21 & 0.000165 & 0.87 & 0.5 \\
\hline
\end{tabular}

atmosphere, the adsorption capacity increased sharply to 23-62 $\mathrm{gH}_{2} \mathrm{~S} / \mathrm{g}_{\text {ads }}$ (dry sewage sludge) and 39-131 $\mathrm{gH}_{2} \mathrm{~S} / \mathrm{g}_{\text {ads }}$ (wet sewage sludge), that is, the thermal treatment favored the adsorption capacity. Castrillon et al. (2016) tested the same activated carbon (it was named Desorex K43-Fe which was impregnated with $\mathrm{Fe}_{2} \mathrm{O}_{3}$, and had specific area of $952 \mathrm{~m}^{2} / \mathrm{g}$ ) at $30^{\circ} \mathrm{C}, 1 \mathrm{~atm}, \mathrm{pH}$ of 7.2 , $\mathrm{H}_{2} \mathrm{~S}$ concentration of $1000 \mathrm{ppm}$, mass of adsorbent of $10 \mathrm{~g}$, and flow rate of $200 \mathrm{~mL} / \mathrm{min}$. They found the adsorption capacity to be $27.88 \mathrm{mgH}_{2} \mathrm{~S} / \mathrm{g}_{\text {ads }}$. Menezes (2017) tested the same Desorex K43-Fe at $25^{\circ} \mathrm{C}, 1 \mathrm{~atm}, \mathrm{pH}$ of $7.2, \mathrm{H}_{2} \mathrm{~S}$ concentration of 200 ppm, mass of adsorbent of $0.69 \mathrm{~g}$, and flow rate of $100 \mathrm{~mL} / \mathrm{min}$. The adsorption capacity was found to be $2.38 \mathrm{mgH}_{2} \mathrm{~S} / \mathrm{g}_{\mathrm{ads}}$.

\subsection{Dynamic adsorption modeling}

The model was tested for three sewage sludge

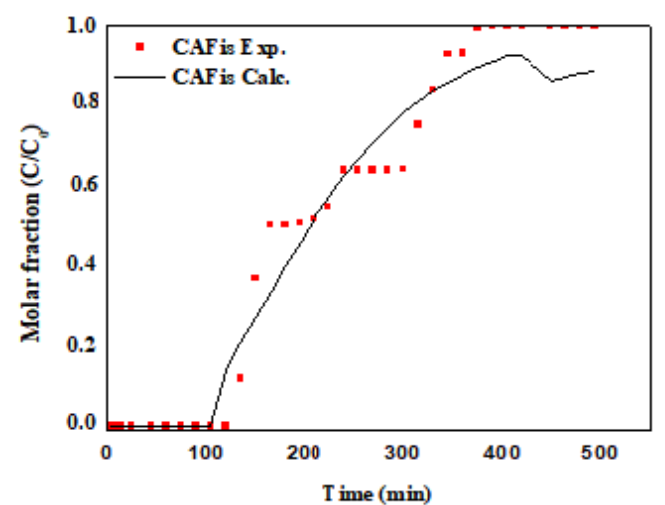

pyrolysis char samples only. Table 4 shows parameters that were determined separately from the model. Bed porosity, particle density, bed density, and fluid phase surface velocity were obtained from other runs but under the same operating conditions (temperature, gas flow rate, and column size) as described before. The porosity of the particle was assumed to be constant and equal to 0.5 considering values reported by Khirevich et al. (2012). This parameter did not affect the response of the model significantly.

The curves obtained by the dynamic model as well as the breakthrough curves obtained from the experimental data are presented in Figure 5. The model fitted well the experimental data and was therefore validated.

As observed from Figure 5 , the ratio $C / C_{o}=1$ indicates that there was no reaction between the

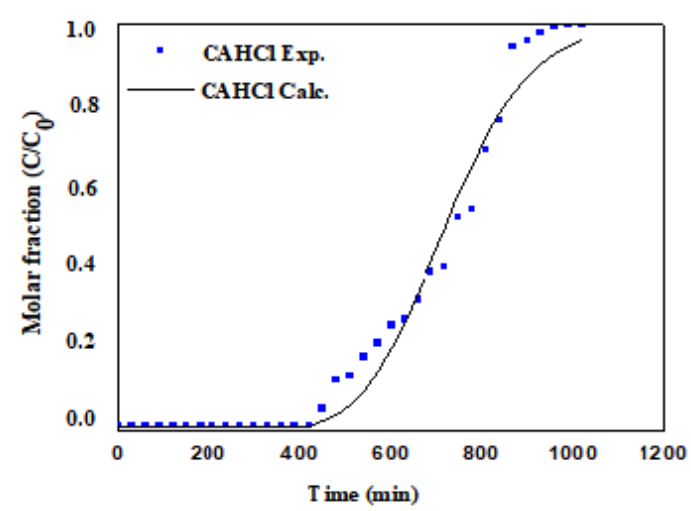

Figure 5. Calculated and experimental breakthrough data for the sewage sludge char samples $\left(\mathrm{CA}_{\mathrm{Fis}}, \mathrm{CA}_{\mathrm{KOH}}\right.$, and $\left.\mathrm{CA}_{\mathrm{HCl}}\right)$. 
Table 5. Estimated adsorption parameters.

\begin{tabular}{cccc}
\hline & $\mathrm{CA}_{\mathrm{Fis}}$ & $\mathrm{CA}_{\mathrm{KOH}}$ & $\mathrm{CA}_{\mathrm{HCl}}$ \\
\hline$k_{s}(\mathrm{dm} / \mathrm{min})$ & $6.62 \times 10^{-5}$ & $1.00 \times 10^{-4}$ & $1.29 \times 10^{-6}$ \\
$D_{e}\left(\mathrm{dm}^{2} / \mathrm{min}\right)$ & $2.73 \times 10^{-2}$ & $4.48 \times 10^{-3}$ & $1.25 \times 10^{-2}$ \\
$D_{L}\left(\mathrm{dm}^{2} / \mathrm{min}\right)$ & $2.90 \times 10^{-6}$ & $1.00 \times 10^{-5}$ & $5.82 \times 10^{-6}$ \\
\hline
\end{tabular}

$\mathrm{H}_{2} \mathrm{~S}$ and the chemical agents in the structure of the adsorbent, which leads to the conclusion that the process occurred in an exclusively physical regime.

The Adsorption parameters estimates are presented in Table 5 . The external mass transfer coefficients should be in the same order of magnitude as the particle size of the char and have the same diameter. The tests were performed under constant gas flow rate. However, because the gas flow rate was low, these values were also low, indicating that the gas transfer through the gaseous film surrounding the particle is slow, consequently the bed should take more time to saturate completely. Nascimento et al. (2017) also tested chars from the pyrolysis of sewage sludge and wood sawdust as $\mathrm{CO}_{2}$ adsorbents and found $k_{s}$ values from $1.52 \times 10^{-4}$ to $1.87 \times 10^{-5} \mathrm{dm} / \mathrm{min}$, which are within the range as the data reported in this work.

The effective diffusivity relates the bed saturation velocity to the pore volume of the adsorbent. In addition, the effective diffusivity is related to the interaction between the adsorbate and the active sites within the pore on the surface of the adsorbent (Luz, 2012). According to Table 5, all values found were in the same order of magnitude. The lowest was for the char treated with $\mathrm{KOH}$, because this particular sample was composed of mesopores $\left(0.075 \mathrm{~cm}^{3} / \mathrm{g}\right)$ and presented a small value for the average pore size (24.6 ̊). Considering the mesopores, the effective diffusivity of the $\mathrm{CA}_{\mathrm{KOH}}$ sample was lower than that of the char sample that did not receive any treatment $\mathrm{CA}_{\mathrm{Fis}}$. In this case, the pore size of $\mathrm{CA}_{\mathrm{KOH}}$ (24.6 $\AA$ ) was smaller than that of $\mathrm{CA}_{\text {Fis }}(2000-1000$ ppm). Nascimento et al. (2014) reported effective diffusivities from $2.22 \times 10^{-3}$ (sewage sludge char) to $3.53 \times 10^{-3} \mathrm{dm}^{2} / \mathrm{min}$ (wood sawdust char). The reason for this might be that the concentration used by this author for $\mathrm{KOH}(2 \mathrm{M})$ was smaller than that used in this work (3M), influenced the physical properties of the adsorbents. The specific area was reported to be $144 \mathrm{~m}^{2} / \mathrm{g}$, the total pore volume was $0.196 \mathrm{~cm}^{3} / \mathrm{g}$, and the average pore size was $54.4 \AA$, against $122 \mathrm{~m}^{2} / \mathrm{g}, 0.075 \mathrm{~cm}^{3} / \mathrm{g}$, and $24.6 \AA$, obtained in the present work.

Axial dispersion across the bed depends on factors such as column length, feed gas flow rate, particle size, and bed porosity. Since the operating conditions were kept constant for the different samples, the values of the axial dispersion through the bed were small for the three char samples, indicating the existence of a flat velocity profile (piston flow) of the $\mathrm{H}_{2} \mathrm{~S}$ through the bed. Different values of the axial dispersion are probably due to change in the porosity of the bed (Delgado, 2006).

\section{CONCLUSIONS}

The use of chars from the pyrolysis of sewage sludge as an adsorbent of $\mathrm{H}_{2} \mathrm{~S}$ can be considered promising since, under the operating conditions used in this study, the chars were able to remove 43.36 to $59.04 \%$ of the $\mathrm{H}_{2} \mathrm{~S}$ from the gas stream. Both chemical agents, $\mathrm{HCl}$ and $\mathrm{KOH}$, enhanced the properties of the chars. One must note that the breakthrough time increased by 4.44 times for the char treated with $\mathrm{HCl}$, however, the percentage of adsorption was lower in comparison to the char treated with $\mathrm{KOH}$. It seems to be necessary to reduce the concentration of this chemical agent, as it can promote the leaching of oxides from the structure of the material. The maximum adsorption capacity (657.6 $\mathrm{mgH}_{2} \mathrm{~S} / \mathrm{g}_{\text {ads }}$ ) was significantly higher than those of the other chars. None of the char samples had the same performance as the activated carbon, which was expected. Nevertheless, given that the chars performed reasonably well, are readily available, and the methodologies for treating them are known and easy to implement, the chars can also be considered a viable alternative as adsorbents. The estimates obtained for the axial diffusivity, effective intraparticle diffusivity, and external mass transfer coefficient are within the same range as 
those reported in the literature. The model was able to predict the dynamic adsorption of $\mathrm{H}_{2} \mathrm{~S}$ on sewage sludge pyrolysis chars successfully.

\section{LIST OF SYMBOLS}

$A_{b c} \quad$ Area above the breakthrough Min curve

$b \quad$ Theoretical adsorption capacity $\mathrm{dm}^{3} / \mathrm{mol}$ in the monolayer

C Concentration of the adsorbate $\mathrm{mol} / \mathrm{m}^{3}$

$C_{i}$ Concentration of the feed $\mathrm{mol} / \mathrm{m}^{3}$

$C_{0}$ Initial concentration of the $\mathrm{mol} / \mathrm{m}^{3}$ adsorbate

$C_{P R}$ Concentration of the gas as a $\mathrm{mol} / \mathrm{m}^{3}$ function of bed length

$C_{t}$ Concentration of the adsorbate $\mathrm{mol} / \mathrm{m}^{3}$ with time

$d_{p} \quad$ Diameter of the particle $\quad \mu \mathrm{m}$

$D$ Diameter of the bed Dm

$D_{e} \quad$ Effective diffusivity $\mathrm{dm}^{2} / \mathrm{min}$

$D_{L} \quad$ Coefficient of axial diffusivity in $\mathrm{dm}^{2} / \mathrm{min}$ the bed

$k_{s} \quad$ External mass transfer coefficient

$L \quad$ Length of the bed

$L_{\text {MTZ }}$ Length of transfer zone

$m_{a d s}$ Mass of adsorbent

$q_{m} \quad$ Maximum adsorption capacity

$q_{R} \quad$ Adsorption capacity

$Q \quad$ Flow rate of the gas phase

$r$ Radial coordinate

$R_{p} \quad$ Radius of the particle

$t \quad$ Time

$t_{e q} \quad$ Time to reach the equilibrium concentration

$v \quad$ Surface velocity

$z \quad$ Axial coordinate

Greek letters

$\varepsilon_{b} \quad$ Porosity of the bed

$\varepsilon_{p} \quad$ Porosity of the particle

$\rho_{b} \quad$ Density of the bed

$\rho_{p} \quad$ Density of the particle

$\tau \quad$ Time used to describe the breakthrough and the bed saturation

\section{REFERENCES}

Abdullah, A. H.; Mat, R.; Aziz A. S. A., Roslan, Use of Kaolin as Adsorbent for Removal of Hydrogen Sulphide from Biogas. Chemical Engineering Transactions, v. 56, p.763-768, 2017. https://dx.doi.org/10.3303/CET1756128

Antonelli, J.; Lindino, C. A.; Azevedo, J. C. R.; Souza, S. N. M.; Cremonez, P. A.; Rossi, E. Biogas production by the anaerobic digestion of whey. Revista de Ciências Agrárias, v. 39:3, p. 463-468, 2016. https://doi.org/10.19084/RCA15087

Bagreev, A.; Locke, D. C.; Bandosz, T. J. $\mathrm{H}_{2} \mathrm{~S}$ Adsorption/Oxidation on Adsorbents Obtained from Pyrolysis of Sewage-Sludge-Derived Fertilizer Using Zinc Chloride Activation. Industrial \& Engineering Chemistry Research, v. 40(16), p. 3502-3510, 2001. https://doi.org/10.1021/ie010165w

Castrillon; M. C; Moura, K. O.; Alves, K. A.; Bastos-Neto, M.; Azevedo, D. C. S.; Hofmann, J.; Möllmer, J.; Einicke, W.-D.; Gläser, R. $\mathrm{CO}_{2}$ and $\mathrm{H}_{2} \mathrm{~S}$ Removal from $\mathrm{CH}_{4}$-rich Streams by Adsorption on Activated Carbons Modified with $\mathrm{K}_{2} \mathrm{CO}_{3}, \mathrm{NaOH}$, or $\mathrm{Fe}_{2} \mathrm{O}_{3}$. Energy \& Fuels, v. 30, p. 9596-9604, 2016. https://doi.org/10.1021/acs.energyfuels.6b01667

Catapan, A.; Catapan, D. C.; Catapan, E. A. Alternative forms of electricity generation from the biogas: An approach to the cost of generation of energy. Custos e Agronegócio, v. 7:1, p. 25-37, 2011.

Ciotola, R. J.; Martin, S. L. J. F. Energy analysis of biogas production and electricity generation from small-scale agricultural digesterse. Ecological Engineering, v. 37, p. 1681-1691, 2011. https://doi.org/10.1016/i.ecoleng.2011.06.031

Delgado, J. M. P. Q. A critical review of dispersion in packed beds. Heat Mass Transfer, v. 42, p. 279-310, 2006. https://doi.org/10.1007/s00231005-0019-0

Garcia, C. G. Montagem e operação de uma unidade de adsorção em leito fixo para remoção de $\mathrm{H}_{2} \mathrm{~S}$ de corrente gasosa. Master's thesis. Programa de Pós-graduação em hidráulica e saneamento, Escola de Engenharia de São Carlos, Universidade de São Paulo, 2014. (In Portuguese). 
Guo, J.; Luo, Y.; Lua, A. C.; Chi, R.; Chen, Y.-L.; Bao, X.-T.; Xiang, S.-X. Adsorption of hydrogen sulphide $\left(\mathrm{H}_{2} \mathrm{~S}\right)$ by activated carbons derived from oil-palm shell. Carbon, v. 45, p. 330-336, 2007. https://doi.org/10.1016/i.carbon.2006.09.016

IUPAC. Pure and Applied Chemistry. IUPAC Recommendations, v. 54, p. 603-619, 1985.

Khirevich, S.; Höltzel, A.; Seidel-Morgenstern, A.; Tallarek, U. Geometrical and topological measures for hydrodynamic dispersion in confined sphere packings at low column-to-particle diameter ratios. Journal of Chromatography A, v. 1262, p. 77-91, 2012.

https://doi.org/10.1016/j.chroma.2012.08.086

Lessa, M. O. Avaliação da capacidade de adsorção do $\mathrm{CO}_{2}$ em zeólita $13 \mathrm{X}$ com gases sintéticos e originados da pirólise do lodo de esgoto. Master's thesis. Programa de PósGraduação em Engenharia Quimica. Universidade Federal do Rio Grande do Norte. 2012. (In Portuguese)

Li, C; Wen, Q; Cai, Z; Zhang, W; Gao, H; Chen, L; Zeng, G; Shu, X; Zhao, Y. Study on activated carbon derived from sewage sludge for adsorption of gaseous formaldehyde. Bioresource Technology, v. 102, p. 942-947, 2011.

https://doi.org/10.1016/i.biortech.2010.09.042

Li, Z. G. Quantification of hydrogen sulfide concentration using methylene blue and 5,5'dithiobis (2-nitrobenzoic acid) methods in plants. Methods in Enzymology, v. 554:101-10, 2015. https://doi.org/10.1016/bs.mie.2014.11.031

Luz, A. D. Aplicação de coluna de adsorção em leito fixo para a remoção de compostos BTX multicomponentes presentes em efluentes petroquímicos. PhD thesis - Departamento de Engenharia Química e Engenharia de Alimentos, Universidade Federal de Santa Catarina, Florianópolis, 2012. (In Portuguese)

Menezes, R. L. C. Estudo do desempenho de carbonos ativados para a remoção de $\mathrm{H}_{2} \mathrm{~S}$ do biogás. Master's thesis, Programa de PósGraduação em Engenharia Química. Universidade Federal do Ceará, 2017. (In Portuguese)
Molino, A; Nanna, F; Ding, Y. B; Braccio, G. B. Biomethane production by anaerobic digestion of organic waste. Fuel Processing Technology, v. 103, p. 1003-1009, 2013.

https://doi.org/10.1016/i.fuel.2012.07.070

Nascimento, A. R.; Figueredo, G. P.; Rodrigues, G.; Melo, M. A. F.; Souza, M. J. B.; Melo, D. M. A. Síntese e caracterização de materiais mesoporosos modificados com níquel para a captura de $\mathrm{CO}_{2}$. Cerâmica, v. 60:356, p. 482-489, 2014. https://doi.org/10.1590/S0366-69132014000400005

Nascimento, P. F. P.; Sousa, J. F.; Oliveira, J. A.; Possa, R. D.; Santos, L. S.; Carvalho, F. C.; J. Ruiz, A. C.; Pedroza, M. M.; Bezerra, M. B. D. Wood Sawdust and Sewage Sludge Pyrolysis Chars for $\mathrm{CO}_{2}$ Adsorption Using a Magnetic Suspension Balance. Canadian Journal of Chemical Engineering, v. 95(11), p. 2148-2155, 2017.

https://doi.org/10.1002/cjce.22861

Pedroza, M. M.; Sousa, J. F.; Vieira, G. E. G.; Bezerra, M. B. D. Characterization of the products from the pyrolysis of sewage sludge in $1 \mathrm{~kg} / \mathrm{h}$ rotating cylinder reactor. Journal of Analytical and Applied Pyrolysis, v. 105, p. 108-115, 2014. https://doi.org/10.1016/i.jaap.2013.10.009

Pedroza, M. M.; Souza, J. F.; Vieira, G. E. G.; Bezerra, M. B. D. Bio-oil and biogas from the pyrolysis of sewage sludge, and non-isothermal degradation on USY zeolite. Brazilian Journal of Petroleum And Gas, v. 11(3), p. 149-163, 2017. https://doi.org/10.5419/bjpg2017-0013

Reese, B. K.; Finneran, D. W.; Mills, H. J.; Zhu, M.-X.; Morse, J. W. Examination and Refinement of the Determination of Aqueous Hydrogen Sulfide by the Methylene Blue Method. Aquatic Geochemistry, v. 17:567, 2011. https://doi.org/10.1007/s10498-011-9128-1

Ros, A.; Montes-Moran, M. A.; Fuente, E.; Nevskaia, D. M.; Martin, M. J. Dried Sludges and Sludge-Based Chars for $\mathrm{H}_{2} \mathrm{~S}$ Removal at Low Temperature: Influence of Sewage Sludge Characteristics. Environmental Science \& Technology, v. 40, p 302-309, 2006. https://doi.org/10.1021/es050996i 
Seredych, M.; Bandosz, T. J. Sewage sludge as a single precursor for development of composite adsorbents/catalysts. Chemical Engineering Journal, v. 128, p. 59-67, 2007. https://doi.org/10.1016/i.cej.2006.06.025

Shang, G.; Shen, G.; Wang, T.; Chen, Q. Effectiveness and mechanisms of hydrogen sulfide adsorption by camphor-derived biochar. Journal of the Air \& Waste Management Association, v. 62:8, p. 873-879, 2012.

https://doi.org/10.1080/10962247.2012.686441

Sousa, J. F.; Bezerra, M. B. D.; Almeida, M. B. B.; Moure, G. T.; Mesa-Pérez, J. M.; Caramao, E. B. Characteristics of Bio-oil from the Fast Pyrolysis of Elephant Grass (Pennisetum purpureum Schumach) in a Fluidized Bed Reactor. American Chemical Science Journal, v. 14(2). p. 1-10, 2016. https://doi.org/10.9734/ACSJ/2016/25843

Sun, Y.; Zhang, J. P.; Wen, C.; Zhang, L. An enhanced approach for biochar preparation using fluidized bed and its application for $\mathrm{H}_{2} \mathrm{~S}$ removal. Chemical Engineering and Processing, v. 104, p. 112, 2016. https://doi.org/10.1016/i.cep.2016.02.006

Vianna, M. M. Obtenção e utilização de produtos de pirólise do lodo de esgoto para adsorção de poluentes em meio aquoso. PhD Thesis. Departamento de Engenharia Química. Universidade de São Paulo, 2013. (In Portuguese)
Wu, C; Jin, B; Song, M; Wu, Y; Huang, Y. Effect of biomass addition on the surface and adsorption characterization of carbon-based adsorbents from sewage sludge. Journal of Environmental Sciences, v. 25, p. 405-412, 2013.

https://doi.org/10.1016/S1001-0742(12)60028-X

Xiao, Y.; Wang, S.; Wu, S.; Yuan, Q. Experimental and simulation study of hydrogen sulfide adsorption on impregnated activated carbon under anaerobic conditions. Journal of Hazardous Materials. v. 153, p. 1193-1200, 2008. https://doi.org/10.1016/j.jhazmat.2007.09.081

Xu, X.; Cao, X.; Zhao, L.; Sun, T. Comparison of sewage sludge- and pig manure-derived biochars for hydrogen sulfide removal. Chemosphere, v. 111, p. 296-303, 2014.

https://doi.org/10.1016/j.chemosphere.2014.04.014

Zilotti, H. A. R. Potencial de produção de biogás em uma estação de tratamento de esgoto de Cascavel para a geração de energia elétrica. Master's thesis. Programa de Pós-Graduação Stricto Sensu em Energia na Agricultura, da Universidade Estadual do Oeste do Paraná, 2012. (In Portuguese). 